\title{
University Professors' Teaching Conceptions Questionnaire: An Instrument to Understand Teaching Models
}

\author{
Noelia Pérez-Rodríguez ${ }^{1}$, Elisa Navarro-Medina² ${ }^{2}$ Nicolás de-Alba-Fernández ${ }^{3}$ \\ 1 University of Seville, Faculty of Education Sciences, Department of Experimental and Social Sciences Education, \\ C/Pirotecnia s/n, ES-41013, Seville, Spain, nperez4@us.es \\ 2 University of Seville, Faculty of Education Sciences, Department of Experimental and Social Sciences Education, \\ C/Pirotecnia s/n, ES-41013, Seville, Spain, enavarro5@us.es \\ 3 University of Seville, Faculty of Education Sciences, Department of Experimental and Social Sciences Education, \\ C/Pirotecnia s/n, ES-41013, Seville, Spain, ndealba@us.es
}

Annotation. This article presents the design, validation using structural equations, and results of a questionnaire about the teaching conceptions of University of Seville professors. Two differentiated samples were used: an experimental group, that included professors who were taking the General University Teaching Course and a control group of professors who were not taking the said course. The results and conclusions of the study show significant differences between the groups.

Keywords: teacher training, conceptions about teaching, university teaching, questionnaire, validation, structural equations.

\section{Introduction}

Higher education faces an important challenge, which is none other than to respond to the problems of today's world. It is essential that students' learning processes be significant, relevant, and useful. Therefore, it is paramount that the role of professors is contemplated in the consecution of quality learning and in the transformation of a university that transmits knowledge to a university that is involved in change and social improvement (Lledó, 2018). 
Attaining this goal is extremely difficult, especially when the university context continues to be dominated by master class teaching styles (Amundsen \& Wilson, 2012; Jiménez Hernández et al., 2020). It all derives from a simple idea that considers any specialist in a scientific discipline to be equipped with the capacity to teach the said subject material, although that person has not been trained for said function (Paricio et al., 2020; Shulman, 1986; Zabalza, 2009). One consequence of this phenomenon is that both in Europe, there is no formal and systematic training for this profession (Rodríguez, 2020). Within the context of Spain, most teacher training is limited to short courses to improve specific aspects of teaching methodology such as resources and tools (Montes \& Suárez, 2016; Pérez-Rodríguez, 2019), but these have no in depth repercussions in changing teaching models. Thus, it is imperative that we forsake anecdotic and volunteer training in isolated elements of teaching to consolidate a didactic training model that is more reflexive and profound.

This current work moved towards teacher-training conception models by studying a specific case. Thus, as the details provided later one, seek to transform teaching conceptions and practice into a teaching model that is more constructivist and research-oriented (Porlán, 2017).

\section{Conception Models about Teaching and University Professor Learning}

When it comes to the conceptions of university professors regarding teaching and learning and the didactic models within which they are organized, is essential to improve teaching (Barrón, 2015; Trigwell \& Prosser, 2020). A number of studies have sought to define the predominating didactic model in university classrooms (Murray \& Macdonald, 1997; Trigwell \& Prosser, 2004; Opfer et al., 2011; Postareff et al., 2008; Postareff \& Lindblom-Ylänne, 2008; Caballero \& Bolívar, 2015; Jiménez Hernández et al., 2020; Yurén et al., 2020). In general, the existence of two opposite teaching models has been established. One focuses on the professor and the material taught (Information Transmission/Teacher-Focused) (ITTF), while the other focuses on the student and the conceptual change (Conceptual Changes/Student-Focused) (CCSF) (Postareff et al., 2008).

Other studies are characterized by more detailed conception models to even establish intermediate models between the two mentioned above. Gargallo et al. (2007) use a Likert questionnaire to address the conceptions of 326 professors from a variety of universities in Spain. Their results prove the existence of four conceptual models. Opposite extremes are held by the CCSF and ITTF models. There are two intermediate models; one is closer to the ITTF model although open to the participation of students but grants priority to the professor as the transmitter of knowledge. The other is closer to the CCSF model, although it fails to have all of its elements.

As the authors describe, the ITTF model understands learning as the accumulation of knowledge from the instructor, using a presentation methodology. Resources include manuals, which are assessed by means of exams to verify the ability of students to 
reproduce contents. The CCSF model conceives knowledge as an individual and social construct between the professor and the student. The instructor works as a learning facilitator who adjusts his/her methodology to students' needs. A variety of resources are used and assessment is processual with continued feedback, which favors students' self-evaluation to become aware of one's own individual strengths and weaknesses.

As Basilisa et al. (2014) stated using an ex post facto design, analyzed the conceptions of one hundred university professors regarding the four learning-related dimensions (What is learning? What is learned? How is it learned? What and how is it evaluated?). In their research, they describe three conception models (direct, interpretive, and constructive). The direct model is similar to the transmissive model, while the constructive model identifies more with student-centered model and conceptual change. The interpretive model is an intermediate type. Nevertheless, as with the previous case, there are two, prenominating opposite models and an intermediate model.

de-Alba-Fernández and Porlán (2020) developed four, progressive teaching models that emerge from empiric results with 48 professors in training. Once again, and as with the aforementioned studies, the opposing extremes show the Transmissive Model-which focuses on the professor and the material (TM) - and the Constructive and Investigative Model—which centers more on students (ICM). Also, there are two intermediate models: the Transmissive model, which is Open to Students (TMOS) and the Closed Problem Resolution Model (CPRM). Both of these models appear in a progression.

Just as de-Alba-Fernández and Porlán (2020) state, this characterization should not be understood as a simple and disconnected relationship of teaching models. The results of their studies show how single instructors share these combinations or "dissonances" in the conception models are commonplace within the scope of university professors' professional development, as proven by other researchers (Postareff et al., 2008; Uiboleht et al., 2016).

\section{Teacher Training for University Professors}

Since the implantation of the European Higher Education Area, teaching approaches have been a standard problem in the university debate (Paricio et al., 2020). These reforms are committed to a teaching model that corresponds to a student-focused model to grant the student greater independence and interaction with knowledge (de-Alba-Fernández \& Porlán, 2020; Fernández \& Madinabeitia, 2020; Paricio et al., 2019).

Research has sought to determine the effects of teacher training on their teaching conceptions with positive results. At the University of Helsinki, Postareff et al. (2008) using a pre-test and a post-test, assessed a program with a sample of 200 professors, divided into four groups, all with different duration and contents. The results showed positive changes in most of the participants, in the sense that they moved closer to more student-focus teaching. 
Gibbs and Coffey (2004), on the other hand, researched the efficiency of teacher training at 22 universities in eight countries. A variety of questionnaires were used, in addition to a pre-test and post-test with a one-year interval. Among other results, the professors participating in the program underwent changes in their teaching conceptions to move towards a more student-centered model. Johannes et al. (2013) also evaluated twelve professors participating in a training program titled "Learning to Teach" with a post-test questionnaire. This author pointed out the positive effects on professional knowledge in terms of conceptions and the focus on contests, active learning, and student participation. Thus, it is pertinent to appreciate teacher training, and consider the most suitable strategies to favor professors' contemplating their practice and to have more student-centered teaching models.

Among the strategies used for teacher training, De Rijdt et al. (2006) pointed out the use of a teaching portfolio as an instrument that facilitates the reflection on one's own practice. Another tool proposed is peer review; this allows the actual teachers to learn more about their own teaching practice from their peers (Murray \& Grant, 1998; Thomas et al., 2014; Da Silva \& Guimarães, 2016). In this regard, Louie et al. (2003) pointed out that the self-analysis process facilitates teacher education by developing new knowledge that arises from researching their own teaching practice. As Yurén et al. (2020) indicated, to change teachers' representations so that these have a more student-centered approach, it is essential that their conceptions be clear and that professors are able to meditate on them.

Another strategy, proposed by Conde-Jiménez and Martín-Gutiérrez (2016) for university teacher training, was the "improvement cycles". This 4-phase system includes: 1) planning to detect those elements eligible for improvement; 2 ) observation in which participants video their own classes; 3 ) the teaching team reviews the video and proposes improvements; and 4) analyze improvement and initiation of a new cycle. These improvement cycles become a tool for reflection, self-evaluation and constant improvement.

Therefore, based on the results of various studies, a teacher training program should have the following traits: a) a university professor-training figure (De la Cruz, 2003) who provides emotional security (Saunders, 2013); b) work units that are constituted as teaching teams (Gómez et al., 2014; Martínez \& Viader, 2008); c) a program that is continual, collaborative, reflective and open in nature (Rodríguez, 2003; Schön, 1991); d) a renovated teaching identity model (Monereo \& Domínguez, 2014); and e) one that is gradual in training times, as changing conceptions is a slow process that requires training that is prolonged over time (de-Alba-Fernández \& Porlán, 2020; Postareff et al., 2008).

\section{Context: The University of Seville Professor Training and Innovation Program}

Since the 2012/2013 academic year, the University of Seville has been developing FIDOP (Programa de Formación e Innovación Docente del Profesorado or Instructor Training and Innovation Program). This program is open to professors, whatever their field of expertise and career, wishing to participate voluntarily. 
FIDOP is organized in two phases (de-Alba-Fernández et al., 2017). For Phase One, instructors take a 100-hour General Course for University Teaching (CGDU, from the Spanish Curso General de Docencia Universitaria). After Phase Two, participants become members of REFID or Teacher Training and Innovation Network (Red de Formación e Innovación Docente).

This current work focuses on Phase One participants; in other words, CGDU. The following aspects characterize this course (de-Alba-Fernández \& Porlán, 2020):

- The training strategy is based upon the implementation of In-classroom Improvement Cycles (or CIMA from the Spanish Ciclos de Mejora en el Aula). All fundamental variables from the curriculum (conception models and practice about contents, methodology and evaluation) are covered in a coherent, simultaneous, and constructive manner (Biggs, 2014). Moreover, other practical problems linked to the professional dimension are covered; these include: the didactic model, conceptions about learning, conceptions about the discipline and professional identity. At all times, the constructivist and research model focusing on students is considered the reference. These In-classroom Improvement Cycles constitute a coming and going process of the reflective action (Karm, 2010), designing and applying changes, assessing the results, and initiating new CIMAs.

- Personal work on one's own teaching practice, both in class (50 hours) as well as remote learning (50 hours) is a fundamental element upon which the course is based and is included in a portfolio.

- Collective work, based on the exchange and discussion among participants, is the standard dynamics used during the sessions. Peer work is an essential training strategy.

- The group of professors is advised by expert trainers in university didactics. This trainer is a reference who provides advice and orients the reflections and designs for improved teaching practice.

- The course-and the program in general-is part of an integrated plan for excellence among professors within the scope of the University of Seville's Third Teaching Plan, in which case, there is institutional coverage.

\section{Materials and Methods}

The research design is quasi-experimental. A post-text evaluation is performed with an experimental group and compared with a control group, in which the dependent variable is the professors' conceptions and independently, their participation in the CGDU. 
The research objectives are:

1. Validate the Questionnaire for University Professors' Teaching Conceptions (UPTC).

2. Compare the conceptions of the professors participating in the CGDU with regards to a group of non-participating professors.

\section{Sample}

For the collection of data, an email was sent to all CGDU participants requesting their participation in the study. Upon accepting, a questionnaire was sent to each participant; simultaneously, an equivalent sample of non-participating professors was sent the same questionnaire. Between April and July of 2018, both groups accessed the sample and data were collected.

The total sample included 251 people. The experimental group $(\mathrm{N}=148)$ took the CGDU between 2013 and 2017, while the control group ( $\mathrm{N}=103)$ were not participants in the FIDOP program phases. Both the experimental and control groups include University of Seville professors. Table 1 provides a description of the sample groups.

Table 1

Sample Characteristics for the Experimental and Control Groups

\begin{tabular}{|c|c|c|c|}
\hline \multicolumn{2}{|c|}{ Characteristics } & $\begin{array}{l}\text { Experimental Group } \\
(\mathrm{N}=148) \mathrm{F}(\%)\end{array}$ & $\begin{array}{l}\text { Control Group } \\
(\mathrm{N}=103) \text { F (\%) }\end{array}$ \\
\hline \multirow{3}{*}{ Gender } & Women & $95(64.6 \%)$ & $43(41.7 \%)$ \\
\hline & Men & $52(35.4 \%)$ & $60(58.3 \%)$ \\
\hline & Total & $147^{*}(100 \%)$ & $103(100 \%)$ \\
\hline \multicolumn{2}{|l|}{ Age $(\mathrm{m})$} & 39.5 & 44 \\
\hline \multirow{4}{*}{$\begin{array}{l}\text { Years of } \\
\text { Experience }\end{array}$} & $<10$ & $92(63.4 \%)$ & $44(43.1 \%)$ \\
\hline & $10-20$ & $38(26.2 \%)$ & $31(30.4 \%)$ \\
\hline & $>20$ & $15(10.3 \%)$ & $27(26.5 \%)$ \\
\hline & Total & $145^{\star}(100 \%)$ & $102^{*}(100 \%)$ \\
\hline \multirow{6}{*}{$\begin{array}{l}\text { Fields of } \\
\text { Knowledge }\end{array}$} & Arts \& Humanities & $28(19.2 \%)$ & $21(20.8 \%)$ \\
\hline & Social Sciences & $32(21.9 \%)$ & $28(27.7 \%)$ \\
\hline & Health Sciences & $25(17.1 \%)$ & $12(11.9 \%)$ \\
\hline & Sciences & $31(21.2 \%)$ & $24(23.8 \%)$ \\
\hline & $\begin{array}{l}\text { Engineering \& } \\
\text { Architecture }\end{array}$ & $30(20.5 \%)$ & $16(15.8 \%)$ \\
\hline & Total & $146^{*}(100 \%)$ & $101^{*}(100 \%)$ \\
\hline
\end{tabular}

Note. ${ }^{\star}$ Lost values 
As can be observed, both groups are heterogeneous and comparable, as they include participating and experienced professors who vary in gender, disciplines, and age. Similarly, the percentages in the categories described are similar. Therefore, the groups could be considered equivalent in characteristics.

\section{Instrument}

A Likert questionnaire was designed to collect data; it focused on collecting information to measure professors' conception models. The items have been built based on previously designed instruments (Abril et al., 2014; Briceño \& Benarroch, 2012; Martín \& Prieto, 2016; Porlán, 1989; Serrano, 2010).

Part one of the two-part questionnaire refers to socio-demographic variables described above. The second part explores four teaching models based on those proposed by de-Alba-Fernández et al. (2020):

- Transmissive Model, focusing on the professor and material (TM).

- Transmissive Model, Open to Students (TMOS).

- Closed Problem Resolution Model (CPRM).

- Constructivist and Investigative Model, focused on students (ICM).

These models are analyzed by considering the interaction between three relevant curricular elements: content, methodology, and evaluation. In the Transmissive Model (TM), contents are merely disciplinary and selected from reference manuals. The methodology focuses on the professor and the subject material. There is no difference between evaluation and grading. In this model, evaluation means "verifying" that students' answers are in line with the work contents. Thus, grading corresponds to the degree of correct or mistaken answers. The TMOS continues to be transmissive, but it begins to consider a change in methodology. Consequently, although the conception of the context is similar, greater prominence is granted to students' learning; for example, student activities to verify the previously explained theoretical content are introduced. The CPRM differs from the two previous elements, as it considers different referents when formulating contents. Beyond the contents of the discipline, students' ideas and representations begin to be taken into account, or even the social and environmental needs of their surroundings. This impacts on the methodology, as the approach to learning contents that differ in nature also implies working from another perspective in the classroom, by means of research projects, case studies problems or similar learning activities. Nevertheless, this approach is carried out within a closed format, as it considers that there is only one possible response when solving problems or cases. Placing students at the center of the methodology also has an impact on grades. In this model, grades should reflect students' learning progression, and not so much the final result. The ICM is important for the investigative and constructive nature of the teaching-learning processes. By considering that certain contents are more relevant and structured than others this grants greater relevance to the process. Importance is also 
rendered to the various activities designed as elements that allow students to construct knowledge.

A total of 13 items, shown in Table 2, were designed for the four models, on a response scale of 1 to 6 , with 1 being "complete disagreement" and 6 "complete agreement".

\section{Table 2}

Description of the Models and Items Making up the Questionnaire

\begin{tabular}{ll}
\hline \multicolumn{1}{c}{ Models } & \multicolumn{1}{c}{ Items } \\
\hline $\begin{array}{l}\text { A1. The grade should reflect the students' degree of correct or } \\
\text { mistaken answers. }\end{array}$ \\
$\begin{array}{l}\text { A2. The subject contents should be selected from manuals and texts } \\
\text { focused on professor \& } \\
\text { the material (TM) }\end{array}$ \\
$\begin{array}{l}\text { A3. Above all else, the contents to be taught at the university should } \\
\text { be the concepts of that scientific discipline. } \\
\text { A4. What I appreciate, especially when evaluating, is that students' } \\
\text { answers are as adjusted as possible to the classroom contents. }\end{array}$
\end{tabular}

B5. My theory classes consist in explaining the content. In the case of practical classes, I prepare a student guideline in advance

Transmissive Model, Open to Students (TMOS) that defines all steps.

B6. Students learn when they incorporate the correct knowledge transmitted by the instructor.

B7. Activities should mainly serve students to clarify, consolidate or verify the theoretical content.

C8. Standard procedure to perform research projects, case studies or similar activities so that students learn contents.

Closed Problem Resolution Model (CPRM)

C9. To design my subject's contents, I take into consideration what students know, the social and environmental needs, the actual discipline, etc.

C10. When grading, I try to indicate each students' progression throughout the learning process.

D11. Teaching is, above all else, efficiently helping students con-

Constructivist \& Investistruct their own knowledge.

gative Model focused on students (CIM)

D12. The class activities between instructor and students should promote students' building knowledge on their own.

D13. There are contents are more valuable than others, as they aid in organizing knowledge.

\section{Analytical Procedures}

Prior to detailing the analytical procedure, it is essential to note that the data matrix was modified for operational purposes. Those items with a negative response were 
inverted to maintain concordance with regards to the rest of the items. Specifically, A1, A2, A3, A4, B5, B6, and B7 have been inverted. To proceed with the data analysis, the psychometric properties of the questionnaire were analyzed first to guarantee both validity and reliability. For this, different processes were followed. First, a trial was carried out with seven (7) experts who assessed the questionnaire content following criteria of clarity and relevance of the items on an ordinal scale from 1 to 5 . To verify the degree of agreement among the judges, Kendall's W test was applied, which is frequently used to assess the degree of agreement among judges when the rating scale is ordinal (Escobar-Pérez \& Cuervo-Martínez, 2008). Secondly, a pilot test with a group of university professors from the CGDU 2018, who were not part of the study sample, was used. Finally, a variety of statistical tests were applied to verify adjustment to the model. Reliability and discriminant validity were obtained by means of McDonald's Omega coefficients, Average Variance Extracted (AVE), and Composite Reliability (CR). To assess the internal consistency of the scale, the Omega ordinal coefficient was chosen as it is the most appropriate for ordinal data that do not comply with the tau-equivalent measurement model (Frias-Navarro, 2020). Construct validity was obtained using an Exploratory Factor Analysis (EFA) from the categorical principal component analysis method with Varimax rotation and Kaiser Normalization.

Once the number of factors was obtained, a Confirmatory Factor Analysis (CFA) was performed to confirm the theoretical model established through Structural Equation Modeling (SEM), which allows a set of observed variables to be listed. In this case, it corresponded to the teachers' conceptions, with different latent variables or factors, referred to in this study to the four teachers' conception models (Bollen, 1989; Ruíz et al., 2010). The AMOS program was used for this analysis, applying the Unweighted Least Squares (ULS) method. This method was chosen because it is considered suitable for Likert-type scales that measure ordinal variables, with polychoric correlations, 3-4 items for each factor, and samples of around 250 cases (Ferrando \& Anguiano Carrasco, 2010; Forero et al., 2009; Morata-Ramírez et al., 2015).

Once the fit of the model had been verified, a comparative study of the conceptions among CGDU participants and non-participants was performed. The Kolmogorov-Smirnov test was used to verify any non-normality assumptions for each dependent variable in the two groups $(\mathrm{p}=.000)$. This led to the use of the Mann-Whitney $\mathrm{U}$ test for independent samples as the most suitable contrast technique. The objective was to test the differences in means between the conceptions of teachers participating in the CGDU and those who did not participate. To test the magnitude of these differences, Cohen's $d$ statistic was used to calculate the effect size, which considered moderate differences to be valued close to .5 (Cohen, 1988). Moreover, the means and standard deviations were calculated for each group, dimensions, and items making up the instrument. 


\section{Results}

\section{Validating the Questionnaire}

Content validation was carried out by seven experts in educational research methodology and university teaching based on each item's degree of relevance and clarity. Kendall's $\mathrm{W}$ test was applied to the findings made to determine the concordance and relevance of the observations, with the result being quite adequate $(\mathrm{W}=.826)$. Later, a pilot test was conducted with twenty (20) teachers with similar characteristics to those of the sample, thus allowing us to modify certain items based on the experts' contributions.

The Composite Reliability (CR) and Average Variance Extracted (AVE) values were also calculated and were adequate for each of the instrument's dimensions. As shown in Table 3, and using the adjustment values proposed by Hair et al. (2010) as the reference, with both the CR and AVE values being adequate for the model fit.

Table 3

Values of Composite Reliability (CR) and Average Variance Extracted (AVE) From the Model

\begin{tabular}{lcccc}
\hline \multicolumn{1}{c}{ Dimensions } & CR & Model Fit & AVE & Model Fit \\
\hline TM & .801 & & .505 & \\
TMOS & .816 & & .596 & \\
CPRM & .804 & CR $>.7$ & .578 & AVE $>.5$ \\
ICM & .764 & & .522 & \\
\hline
\end{tabular}

To validate the construct, an EFA was carried out. Previously, the construct validation was carried out by means of an AFE. In a previous step, the Kaiser-Meyer-Olkin (KMO) test and Bartlett's test of sphericity were carried out. In the case of the KMO test a high score close to 1 and (.78) and for Bartlett's test of sphericity, the value was $p=.00$. Both indexes allow us to confirm the suitability of the data matrix to proceed with the factor analysis. An analysis of main categorical components was performed, with Varimax rotation, to obtain four factors or dimensions with an explained variance of $61.6 \%$ : TM, TMOS, CPRM and CIM dimensions. As shown in the rotated component matrix (Table 4), all items have factor weights greater than .618 in their component or dimension. Also, the reliability of the instrument was obtained using McDonald's Omega coefficient overall (.93). All of the above substantiates the internal consistency of the instrument. 
Table 4

Rotated Component Matrix

\begin{tabular}{lllll}
\hline \multirow{2}{*}{ Items } & \multicolumn{4}{c}{ Component or Dimension } \\
\cline { 2 - 4 } & TM & TMOS & CPRM & CIM \\
\hline A1 & .618 & & & \\
A2 & .634 & & & \\
A3 & .808 & & & \\
A4 & .765 & & & \\
B5 & & .779 & & \\
B6 & & .774 & .731 & \\
B7 & & .764 & .788 & \\
C8 & & & .760 & \\
C9 & & & & .801 \\
C10 & & & & .626 \\
D11 & & & & \\
D12 & & & \\
D13 & & & \\
\hline
\end{tabular}

The theoretical model is confirmed thanks to an CFA. As shown in Figure 1, the item-dimension relationship values range from .26 to .83 . The TM-TMOS dimensions also have a positive correlation (.69) and so do the CPRM-CIM dimensions (.49).

\section{Figure 1}

Structural Diagram of the Questionnaire "University Professors' Teaching Conceptions" (UPTC)

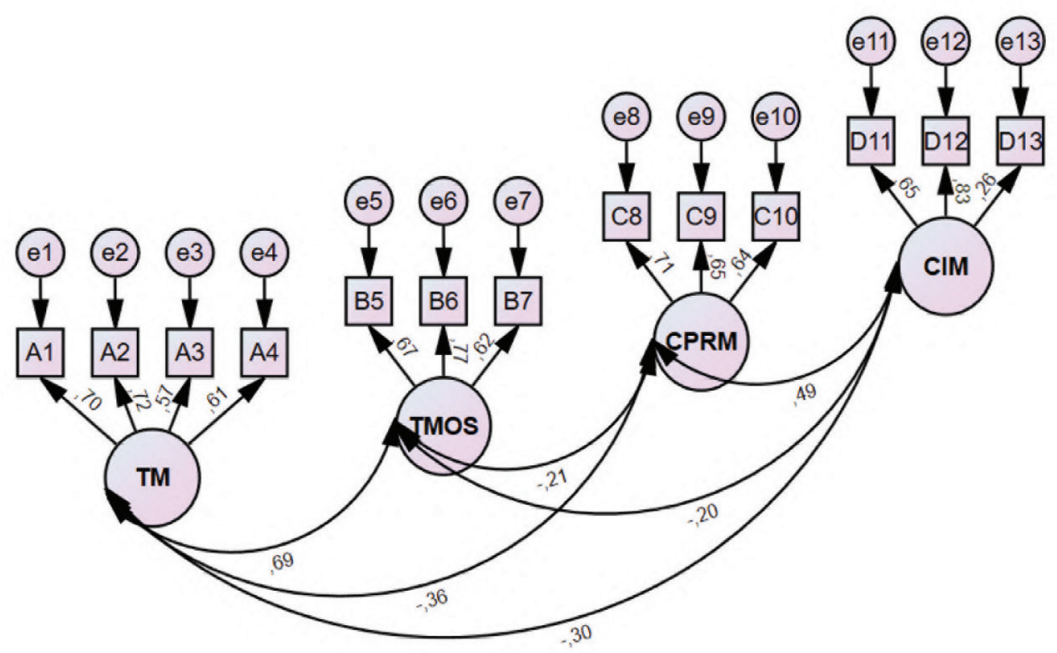


However, all other correlations among the dimensions are negative. This result confirms the theoretical model based on two totally opposite dimensions (TM-ICM) with a negative correlation (-.30); and at the same time, two intermediate teaching models. Likewise, the model's goodness-of-fit indexes fit, as shown in Table 5. The fit indexes considered are those proposed by Levy Mangin et al. (2006): chi-square (CMIN), goodnessof-fit index (GFI), normalized fit index (NFI) and normalized parsimony fit index (PNFI).

\section{Table 5}

Index for Model Fit

\begin{tabular}{lcc}
\hline \multicolumn{1}{c}{ Index } & Result & Model Fit \\
\hline CMIN & 116.71 & CMIN $<500$ \\
GFI & .984 & GFI $>.7$ \\
NFI & .964 & NFI $>.7$ \\
PNFI & .729 & PNFI $>.7$ \\
\hline
\end{tabular}

\section{Professors' Conception Models}

The second objective of this study focuses on analyzing the existing differences when comparing the conceptions between those teachers participating in the CGDU and those who do not. For this purpose, statistical tests were used to differentiate the groups. Table 6 shows that there are significant differences $(\mathrm{p}<.05)$ between both groups for the four dimensions compared. Cohen's $d$ values close to .50 show that the differences between the groups are moderate. The CIM dimension shows the most significant differences between the groups.

Table 6

Contrast Statistics for the Study's Dimensions

\begin{tabular}{lccc}
\hline \multicolumn{1}{c}{ Dimensions } & U de Mann-Whitney & $\mathbf{p}$ & $\mathbf{d}$ \\
\hline TM & 5543.5 & .01 & .34 \\
TMOS & 5779.0 & .01 & .38 \\
CPRM & 5452.5 & .00 & .40 \\
CIM & 5227.0 & .00 & .52 \\
\hline
\end{tabular}

Note. p (signification), d (Value for Cohen's d).

As described in Table 7, which shows the means and standard deviations for the items making up each dimension, one observes that for the dimensions TM and TMOS, the control group has scores on the scale that are closer to $6(\mathrm{M}=3.64$ and $\mathrm{M}=4.28$, respectively) when compared to the experimental group $(M=3.31$ and $M=3.87$, respectively). 
In the case of the CPRM and ICM dimensions, the opposite occurs: the experimental group ( $M=4.59$ and $M=5.29$, respectively) has scores that are closer to $6(M=4.20$ and $\mathrm{M}=4.93$, respectively) than the control group. Therefore, the control group shows higher scores in the teacher-centered teaching models (TM and TMOS), while the experimental group exhibits higher scores in the student-centered models (CPRM and ICM).

Table 7

Means and Standard Deviations for Items and Dimensions (Experimental and Control Groups)

\begin{tabular}{|c|c|c|c|c|}
\hline \multirow{2}{*}{$\begin{array}{c}\text { Dimensions } \\
\text { Items }\end{array}$} & \multicolumn{2}{|c|}{ Experimental Group } & \multicolumn{2}{|c|}{ Control Group } \\
\hline & $\mathbf{M}$ & DT & $\mathbf{M}$ & DT \\
\hline A1 & 3.18 & 1.37 & 3.66 & 1.37 \\
\hline A2 & 3.42 & 1.29 & 3.70 & 1.21 \\
\hline A3 & 3.24 & 1.32 & 3.65 & 1.18 \\
\hline A4 & 3.35 & 1.24 & 3.55 & 1.14 \\
\hline TM & 3.31 & .99 & 3.64 & .93 \\
\hline B5 & 3.96 & 1.52 & 4.48 & 1.41 \\
\hline B6 & 3.61 & 1.59 & 3.89 & 1.23 \\
\hline B7 & 4.05 & 1.27 & 4.42 & 1.10 \\
\hline TMOS & 3.87 & 1.18 & 4.28 & .99 \\
\hline $\mathrm{C} 8$ & 4.59 & 1.29 & 4.15 & 1.37 \\
\hline $\mathrm{C} 9$ & 4.65 & 1.19 & 4.41 & 1.11 \\
\hline $\mathrm{C} 10$ & 4.51 & 1.18 & 4.04 & 1.38 \\
\hline CPRM & 4.59 & .97 & 4.20 & 1.00 \\
\hline D11 & 5.39 & .79 & 5.12 & .87 \\
\hline D12 & 5.30 & .87 & 4.93 & 1.01 \\
\hline D13 & 5.20 & .82 & 4.73 & 1.17 \\
\hline CIM & 5.29 & .59 & 4.93 & .77 \\
\hline
\end{tabular}

Note. M (Mean), DT (Standard Deviation).

\section{Discussion}

The validation of the questionnaire for this study using structural equations garners value to the theoretical structure, supported by multiple research that even when they point to the existence of two opposite didactic models, they also contemplate the existence 
of intermediate models (Basilisa et al., 2014; de-Alba-Fernández \& Porlán, 2020; Gargallo et al., 2007; Postareff et al., 2008). As already presented, the conceptions of professors participating in the CGDU indicate that trainee instructors show higher scores in the student-centered models (CPRM and ICM dimensions of the study). These results are consistent with those of Postareff et al. (2008), Gibbs and Coffey (2004), and Johannes et al. (2013).

As Ho et al. (2001) point out, teacher training programs should follow a training strategy that is focused on teaching practice to achieve better results. In the conclusions of their study, where they evaluate the effectiveness of a teacher training program at the University of Hong Kong, this author states that two-thirds of the total sample succeeded in changing their conceptions. Their program followed a strategy similar to that of the CGDU, which may be summarized as: a) awareness of their implicit conceptions; b) a problematizing process and discussion about their conceptions; c) exposure to other conceptions through other instructors; and d) redesign a topic with the objective of committing to achieving greater coherence between their conceptions and their practices. This is also confirmed by the results of this research. As stated previously, when contextualizing this current study, the CGDU is committed to training based on the design and implementation of Classroom Improvement Cycles, which entail contemplating the actual teaching practice. This is consistent with studies that advocate starting from meditating on one's own practice in the necessary cyclical exchange of going from practice to theory, to detect obstacles, design changes, implement and evaluate them (Conde-Jiménez \& Martín-Gutiérrez, 2016; Louie et al., 2003). However, there is research that shows that teacher training continues to be approached mostly from a perspective that is isolated from the teaching practice and is poorly linked to the real needs and problems arising in the classroom (González \& Raposo, 2008; Pérez-Rodríguez, 2019).

On the other hand, the results of our study show how teaching conception models, described as opposing, co-exist in the same teacher. This is consistent with the results of Uiboleht et al. (2016). In their research, through a multiple case study, they sought to discover the "uniformity" and "discordancy" in descriptions that teachers provide for the various aspects of their teaching practice. The goal was to determine how instructors combined a wide range of teaching approaches within a single course. As a result, the study found a high frequency of discordancy within a single teacher. The authors point out that this could be due to a lack of pedagogical awareness, as Postareff \& Lindblom-Ylänne (2008) have also pointed out. Therefore, it is important to emphasize that to develop professors' pedagogical awareness, the rhythms and gradualness of the training processes need to be respected. Over time, and with sustained and accompanied training, instructors progressively consolidate a coherent and internally aligned didactic model, including theoretical and practical levels (Biggs, 2014). 


\section{Conclusions}

The results of this study show that certain training strategies favor how professors approach teaching conceptions that are more focused on the students. On the other hand, teaching models do not appear in a pure form. Thus, it is normal for the same teacher to show traits of different models at the same time. This reinforces the idea that training processes must be gradual and sustained over time, so that progressive and permanent changes can take place.

In lieu of this, deepening into teachers' conception models allows them to consider the existing discordances and uniformities as their starting point to design strategies that allow them to improve their teaching practice. As a future perspective, and within the framework of the University of Seville Professor Training Program, it will be interesting to reapply this scale to professors participating in the permanent phase of the program (REFID), which will allow the authors to analyze how these discordances occur in the conception models when the instructors have further training and have implemented innovations in the classroom. This will enrich the knowledge-based regarding the impact of the program on the improvement of the teaching and learning processes while obtaining results about the effect of gradualness and sustained training over time on changes in instructors' conceptions.

Likewise, comparative studies will be considered among professors in training at a number of universities in Spain. This will facilitate the analysis of other variables such as the strategies followed by the numerous programs or contextual variables. The idea is to progressively obtain results on the impact of training on improved university teaching. Ultimately, this will allow the authors to extrapolate and disseminate these good-practice training models.

\section{Funding}

This work was supported by the Spain's Ministry of Economy and Competitiveness under Grant number EDU2016-75604-P University Professor Training: Participants' progress and obstacles in a program based on their teaching practice improvement cycles; University of Seville (5th University Plan for Research and Exchange Funding Agency) under Grant number USE-18648-H doctoral thesis by Noelia Pérez-Rodríguez.

\section{References}

Abril, A. M., Ariza M, R., Quesada, A., \& García, F. J. (2014). Inquiry-based learning in secondary school: in-service and pre-service teachers' believes. Revista Eureka, 11(1), 22-33. 
Amundsen, C., \& Wilson, M. (2012). Are we asking the right questions? A conceptual review of the educational development literature in higher education. Review of Educational Research, 82(1), 90-126. https://doi.org/10.3102/0034654312438409

Barrón, C. (2015). Epistemological conceptions and teaching practices. A review. REDU-Revista de Docencia Universitaria, 13(1), 35-56.

Basilisa, M., Mateos, M., \& Vilanova, S. (2014). Questionnaire on dilemmas to investigate conceptions on learning in university teachers. Docencia Universitaria, 15, 103-120.

Biggs, J. (2014). Constructive alignment in university teaching. HERDSA Review of Higher Education, 1, 5-22. https://doi.org/10.1046/j.1365-2923.1999.00431.x

Bollen, K. A. (1989). Structural equations with latent variables. New York: John Wiley y Sons.

Briceño, J. J., \& Benarroch, A. (2012). Conceptions and beliefes in science, learning and teaching of university teachers. Revista Electrónica de Investigación en Educación en Ciencias, 8(1), 24-41.

Caballero, K., \& Bolívar, A. (2015). Academics' identity as teachers: towards the scholarship of teaching and learning. REDU-Revista de Docencia Universitaria, 13(1), 57-77. Retrieved from http://red-u.net/redu/index.php/REDU/article/view/900

Cohen, J. (1988). Statistical power analysis for the behavioral science (2nd ed.). Lawrence Erlbaum Associates.

Conde-Jiménez, J., \& Martín-Gutiérrez, Á. (2016). The potential and need for improvement in the training of new university lecturers. Revista Electrónica de Investigación Educativa, 18(1), 140-152. https://redie.uabc.mx/redie/article/view/767

Da Silva, M. M., \& Guimarães, B. (2016). Peer instruction: continuing teacher education in higher education. Procedia - Social and Behavioral Sciences, 217, 249-256. https://doi.org/10.1016/j. sbspro.2016.02.078

De la Cruz, M. Á. (2003). Necesidad y objetivos de la formación pedagógica del profesor universitario [Necessity and objectives of university teacher training]. Revista de Educación, 331, 35-66.

De Rijdt, C., Tiquet, E., Dochy, F. \& Devolder, M. (2006). Teaching portfolios in higher education and their effects: An explorative study. Teaching and Teacher Education, 22(8), 1084-1093. https://doi.org/10.1016/j.tate.2006.07.002

de-Alba-Fernández, N. \& Porlán, R. (2020). Docentes universitarios. Una formación centrada en la práctica [University professors. A training focused on practice]. Morata.

de-Alba-Fernández, N., Duarte, D., Hamed, S., Navarro, E., \& Porlán, R. (2017). Una propuesta para la innovación docente y la formación del profesorado universitario [A proposal for teaching innovation and university profesor training]. En P. Membiela, N. Casado, M. I. Cebreiros, \& M. Vidal, Investigación y práctica en la Educación Superior [Research and practice in higher education] (pp. 279-283). Educación Editora.

de-Alba-Fernández, N., Navarro-Medina, E., Porlán, R., \& Pérez-Rodríguez, N. (2020). La progresión de los modelos docentes universitarios: Resultados del primer estudio [The Progression of University Teaching Models: Results of the First Study]. En N. de-Alba-Fernández, \& R. Porlán, 
Docentes universitarios. Una formación centrada en la práctica [University professors. A training focused on practice] (pp. 191-230). Morata.

Escobar-Pérez, J., \& Cuervo-Martínez, A. (2008). Validez de contenido y juicio de expertos: una aproximación a su utilización [Content validity and expert judgement: an approach to their use]. Avances en Medición, 6, 27-36.

Fernández, I., \& Madinabeitia, A. (2020). Teaching transformation of the university after twenty years of Bologna: Balance and keys for a future to be defined. Profesorado, 24(2), 28-52. https://doi.org/10.30827/PROFESORADO.V24I2.15149

Ferrando, P., \& Anguiano Carrasco, C. (2010). Factor analysis as a research technique in psychology. Papeles del Psicólogo, 31(1), 18-33.

Forero, C. G., Maydeu, A., \& Gallardo, D. (2009). Factor analysis with ordinal indicators: A Monte Carlo study comparing DWLS and ULS estimation. Structural Equation Modeling, $16,625-641$.

Frias-Navarro, D. (2020). Apuntes de consistencia interna de las puntuaciones de un instrumento de medida [Notes on the internal consistency of the scores of a measuring instrument]. University of Valencia. https://www.uv.es/friasnav/AlfaCronbach.pdf

Gargallo, B., Fernández, A. \& Jiménez, M. A. (2007). Teaching models of university professors. Teoría de La Educación, 19, 167-189.

Gibbs, G., \& Coffey, M. (2004). The impact of training of university teachers on their teaching skills, their approach to teaching and the approach to learning of their students. Active Learning in Higher Education, 5(1), 87-100. https://doi.org/10.1177\%2F1469787404040463

Gómez, M., Escofet, A., \& Freixa, M. (2014). The teaching staff in higher education. Utopia or reality? Revista Española de Pedagogía, (259), 509-523.

González, M., \& Raposo, M. (2008). Necesidades formativas del profesorado universitario en el contexto de la convergencia europea [Training needs of university teaching staff in the context of European convergence]. Revista de Investigación Educativa, 26(2), 285-306.

Hair, J., Black, W., Babin, B., \& Anderson, R. (2010). Multivariate data analysis. Prentice-Hall. Cengage Learning EMEA.

Ho, A., Watkins, D., \& Kelly, M. (2001). The Conceptual Change Approach to Improving Teaching and Learning: An Evaluation of a Hong Kong Staff Development Programme. Higher Education, 42, 143-169.

Jiménez Hernández, D., González Ortiz, J. J., \& Tornel Abellán, M. (2020). Active methodologies in the university and their relationship with teaching approaches. Profesorado-Revista de Curriculum y Formacion de Profesorado, 24(1), 76-94. https://doi.org/10.30827/profesorado. v24i1.8173

Johannes, C., Fendler, J., \& Seidel, T. (2013). Teachers' perceptions of the learning environment and their knowledge base in a training program for novice university teachers. International Journal for Academic Development, 18(2), 152-165. https://doi.org/10.1080/1360144X.2012.681785

Karm, M. (2010). Reflection tasks in pedagogical training courses. International Journal for Academic Development, 15(3), 203-214. https://doi.org/10.1080/1360144X.2010.497681. 
Lévy Mangin, J. P., Varela Mallou, J., \& Abad González. J. (2006). Modelización con estructuras de covarianzas en ciencias sociales: temas esenciales. Avanzados y aportaciones especiales [Modelling with covariance structures in the social sciences: essential topics. Advanced and special contributions]. Netbiblo.

Lledó, E. (2018). Sobre la educación [About education]. Taurus.

Louie, B. Y., Drevdahl, D. J., Purdy, J. M., \& Stackman, R. W. (2003). Advancing the scholarship of teaching through collaborative self-study. The Journal of Higher Education, 74(2), 150-171.

Martín, C., \& Prieto, T. (2016). Creencias de profesorado de secundaria en formación inicial sobre su papel en el aula de ciencias [Beliefs of secondary school teachers in initial training about their role in the science classroom]. En J. L. Bravo Galán, 27 Encuentros en Didáctica de las Ciencias Experimentales [27th Meetings in Didactics of Experimental Sciences] (pp. 1271-1278). https://cutt.ly/MgPigCV

Martínez, M., \& Viader, M. (2008). Learning and teaching in a context of change in the university. The promotion of Teaching Team. Revista de Educación, (número extraordinario), 213-234.

Monereo, C., \& Domínguez, C. (2014). The teaching identity of competent university teachers. Educación XX1, 17(2), 83-104. https://doi.org/10.5944/educxx1.17.2.11480.

Montes, D. A. \& Suárez, C. I. (2016). Teacher training in universities: key aspects of training in Spanish universities. Revista Electrónica de Investigación Educativa, 18(3), 52-64.

Morata-Ramírez, Ma. A., Holgado-Tello, F. P., Barbero-García, I., \& Méndez, G. (2015). Confirmatory factor analysis. Recommendations for unweighted least squares method related to Chi-Square and RMSEA Type I error. Acción psicológica, 12(12), 79-90. http://dx.doi. org/10.5944/ap.12.1.14362

Murray, C. E., \& Grant, G. (1998). Teacher peer review: Possibility or pipedream? Contemporary Education, 69(4), 202-204.

Murray, K., \& Macdonald, R. (1997). The disjunction between lecturers' conceptions of teaching and their claimed educational practice. Higher Education, 33(3), 331-349.

Opfer, V. D., Pedder, D. G., \& Lavicza, Z. (2011). The role of teachers' orientation to learning in professional development and change: A national study of teachers in England. Teaching and Teacher Education, 27, 443-453. https://doi.org/10.1016/j.tate.2010.09.014

Paricio, J., Fernández, A., \& Fernández, I. (2019). Cartografía de la buena docencia universitaria. Un marco para el desarrollo del profesorado basado en la investigación [Mapping good university teaching. A framework for research-based faculty development]. Narcea Ediciones.

Paricio, J., Zabalza, M. Á., \& Trillo, F. (2020). Twenty years of change in higher education: achievements, failures and pending challenges. Homage to Miguel Ángel Zabalza. REDURevista de docencia Universitaria, 18(1), 9-15.

Pérez-Rodríguez, N. (2019). Teacher training programs in higher education in the Spanish context. Investigación en la escuela, (97), 1-17. https://doi.org/10.12795/IE.2019.i97.01

Porlán, R. (1989). Teoría del conocimiento, teoría de la enseñanza y desarrollo profesional. Las concepciones epistemológicas de los profesores [Theory of knowledge, teaching theory and 
professional development. Epistemological conceptions of teachers] (Doctoral dissertation). University of Seville. https://dialnet.unirioja.es/servlet/libro?codigo=46159

Porlán, R. (2017). Enseñanza universitaria. Cómo mejorarla [University teaching. How to improve it.]. Morata.

Postareff, L., \& Lindblom-Ylänne, S. (2008). Variation in teachers' descriptions of teaching: Broadening the understanding of teaching in higher education. Learning and Instruction, 18, 109-120. https://doi.org/10.1016/j.learninstruc.2007.01.008

Postareff, L., Lindblom-Ylänne, S. \& Nevgi, A. (2008). The effect of pedagogical training on teaching in higher education. Teaching and Teacher Education, 23, 557-571. https:/doi. org/10.1016/j.tate.2006.11.013

Rodríguez, S. (2003). Nuevos retos y enfoques en la formación del profesorado universitario [New challenges and approaches in university teacher education]. Revista de Educación, (331), 67-69.

Rodríguez, S. (2020). Lights and shadows in the pedagogical training of university faculty in Spain. REDU-Revista de Docencia Universitaria, 18(1), 143-168. https://doi.org/10.4995/ redu.2020.13183

Saunders, R. (2013). The role of teacher emotions in change: Experiences, patterns and implications for professional development. Journal of Educational Change, 14(3), 303-333. https://doi. org/10.1007/s10833-012-9195-0

Schön, D. (1991). The reflective practitioner: How professionals think in action. Oxford: Avebury.

Serrano, R. C. (2010). Teacher's thoughts: an introduction to the beliefs and conceptions about the teaching-learning process on Higher Education. Revista de Educación, 352 (mayo-agosto), 267-287.

Shulman, L.S. (1986). Those who understand: knowledge growth in teaching. Educational Researcher, 15(2), 3-14.

Thomas, S., Chie, Q. T., Abraham, M., Jalarajan, S., \& Beh, L. S. (2014). A qualitative review of literature on peer review of teaching in higher education: An application of the SWOT framework. Review of Educational Research, 84, 112-159. https://doi.org/10.3102/0034654313499617

Trigwell, K., \& Prosser, M. (2004). Development and use of the approaches to teaching inventory. Educational Psychology Review, 16(4), 409-424. https://doi.org/10.1007/s10648-004-0007-9

Trigwell, K., \& Prosser, M. (2020). Exploring university teaching and learning. Experience and Context. Palgrave MacMillan.

Uiboleht, K., Karm, M., \& Postareff, L. (2016). How do university teachers combine different approaches to teaching in a specific course? A qualitative multi-case study. Teaching in Higher Education, 21(7), 854-869. https://doi.org/10.1080/13562517.2016.1183615

Yurén, T., Garcia-Garcia, F. J., Escalante Ferrer, A. E., González-Barrera, Z., \& Velazquez Albavera, D. J. (2020). Representations of university teaching quality: Instructional and constructivist focuses. Revista Mexicana de Investigación Educativa, 25(85), 239-265.

Zabalza, M. Á. (2009). Ser profesor universitario hoy [Being a university professor today]. La Cuestión Universitaria, (5), 68-80. 


\title{
Universiteto dèstytojų mokymo koncepcijų klausimynas: instrumentas mokymo modeliams suprasti
}

\author{
Noelia Pérez-Rodríguez ${ }^{1}$, Elisa Navarro-Medina ${ }^{2}$, Nicolás de-Alba-Fernández ${ }^{3}$
}

Sevilijos universitetas, Edukologijos fakultetas, Eksperimentinių ir socialinių mokslų ugdymo katedra, C/Pirotecnia s/n, ES-41013, Sevilija, Ispanija, nperez4@us.es

2 Sevilijos universitetas, Edukologijos fakultetas, Eksperimentinių ir socialinių mokslų ugdymo katedra, C/Pirotecnia s/n, ES-41013, Sevilija, Ispanija, enavarro5@us.es

3 Sevilijos universitetas, Edukologijos fakultetas, Eksperimentinių ir socialinių mokslų ugdymo katedra, C/Pirotecnia s/n, ES-41013, Sevilija, Ispanija, ndealba@us.es

\section{Santrauka}

Šiame straipsnyje pateikiamas Sevilijos universiteto dėstytojų mokymo koncepcijų klausimyno dizainas, validacija ir rezultatai pagal kvazieksperimentinio tyrimo planą. Šiam tyrimui atlikti buvo naudojamos dvi diferencijuotos imtys: eksperimentine grupe $(\mathrm{N}=148)$, kurią sudarè dèstytojai, lankę bendrąji universiteto mokymo kursą (angl. General Course for University Teaching (CGDU)), ir kontrolinė dėstytojų, kurie nelankè minèto kurso, grupè ( $\mathrm{N}=103)$. Likerto skalès klausimyne buvo pateikti keturi mokymo koncepcijų modeliai, t. y. i mokytoją orientuotas modelis: orientuotas ị dėstytoją ir mokomąją medžiagą (angl. transmissive model (TM)), i mokytoją orientuotas modelis: atviras studentams (angl. transmissive model, open to students (TMOS)), ị studentą orientuotas modelis: uždarojo problemų sprendimo modelis (angl. closed problem resolution model (CPRM)), ị studentą orientuotas modelis: konstruktyvistinis ir tiriamasis modelis (angl. constructivist and investigative model, focused on students (ICM)).

Pirma, autoriai validavo instrumentą naudodami struktūrines lygtis. Vèliau testas buvo pritaikytas abiem grupėms, siekiant sužinoti vidutinius jų atsakymų skirtumus. Tyrimo rezultatai ir išvados rodo statistiškai reikšmingus grupių skirtumus pagal keturis analizuotus mokymo modelius. Reikšmingiausi skirtumai išryškëja konstruktyvistinio ir tiriamojo modelio dimensijoje. Dėstytojų, lankančių bendrąji universiteto mokymo kursą, balai buvo aukštesni nei kontrolinès grupès. Skirtumai tarp dviejų grupių gali būti paaiškinti kurso metu išvystyta dinamika, todèl kurse naudojamos mokymo strategijos yra tinkamos priartinti universiteto dèstytojus prie šio mokymo modelio.

Esminiai žodžiai: mokytoju rengimas, mokymo koncepcijos, universitetinis mokymas, klausimynas, patvirtinimas, struktūrinès lygtys. 